\title{
Identyfikacja obiektów antropogenicznych na archiwalnych zdjęciach lotniczych okolic Jedwabnego
}

\author{
Anna Mirończuk, Zenon F. Poławski
}

\section{Wprowadzenie}

Wieloletnie doświadczenia Instytutu Geodezji Kartografii wskazują na znaczącą rolę archiwalnych zdjęć lotniczych w analizach retrospektywnych. Dzięki rejestracji pełnego obrazu wszystkich elementów występujących na powierzchni ziemi stają się one obiektywnym materiałem dla detekcji obiektów i obszarów historycznych, szczególnie wtedy gdy zawodzą tradycyjne metody oparte na dokumentacji historyczno-kartograficznej.

W 1858 r. Gaspard-Félix Tournachon dał początek fotografii lotniczej, wykonując na szklanej płytce czarno-białe zdjęcie fragmentu Paryża. Aby tego dokonać, uniósł się nad miastem w swoim balonie. Rozwój fotografii lotniczej przypada jednak dopiero na czas pierwszej i drugiej wojny światowej, kiedy to tego rodzaju zdjęcia stanowiły podstawę rozpoznania terenowego i były wykorzystywane głównie do celów wojskowych. W Polsce w okresie międzywojennym zdjęcia lotnicze wykonywał Wojskowy Instytut Geograficzny, wykorzystując je głównie do opracowań map topograficznych. W 1930 r. przy Polskich Liniach Lotniczych powołano Wydział Aerofotogrametryczny, który sporządzał podkłady fotogrametryczne dla celów urbanistycznych, melioracyjnych i budowlanych.

Po wojnie zdjęcia lotnicze stały się nie tylko podstawowym materiałem dla opracowań różnoskalowych map topograficznych, ale zaczynały również znajdować coraz większe zastosowanie w pracach nietopograficznych.

Rozwój nietopograficznych zastosowań fotografii lotniczej obserwujemy na pocz. lat 60 . $\mathrm{XX}$ w. Materiały te zaczęto wykorzystywać m.in. w planowaniu przestrzennym, kartografii geologicznej, urządzaniu lasu czy ocenie stanu środowiska ${ }^{1}$.
Archiwalnymi zdjęciami lotniczymi posługiwano się w studiach historyczno-geograficznych. Jednym z wielu przykładów jest „Atlas miast śląskich”, który przedstawia etapy rozwoju przestrzennego 34 wybranych miast regionu od pocz. XIX w. po dzień dzisiejszy. Do detekcji zaprezentowanych $\mathrm{w}$ nim obszarów i obiektów historycznych wykorzystano, obok źródeł pisanych i map, zdjęcia lotnicze $\mathrm{z}$ lat 40. XX w. zgromadzone w zbiorach Instytutu Herdera w Marburgu².

Innym przykładem jest opracowana na podstawie niemieckich zdjęć lotniczych z 1942, 1943 i 1944 r. topograficzna dokumentacja miejsca zbrodni NKWD na polskich oficerach. Sporządzone w wyniku interpretacji zdjęć lotniczych mapy (szkice fotointerpretacyjne) są jak dotąd jedynym materiałem kartograficznym przedstawiającym obszar lasu katyńskiego w tak dokładnej skali ${ }^{3}$.

Fotogrametryczna analiza archiwalnych fotoplanów i zdjęć lotniczych znalazła zastosowanie także w ewidencji gruntów i budynków, stanowiąc $\mathrm{w}$ wielu przypadkach jedyne narzędzie do odtwarzania przebiegu historycznych granic działek ewidencyjnych, kontroli prawidłowości ich przebiegu oraz określania sposobu użytkowania działek ewidencyjnych w kontekście zasiedzenia ${ }^{4}$.

${ }_{1}$ A. Ciołkosz, J. Mieszalski, J.R. Olędzki, Interpretacja zdjęć lotniczych, Państwowe Wydawnictwo Naukowe, Warszawa 1999, s. 11-17.

2 https://www.herder-institut.de/atlas-miast-slaskich, dostęp: 13 listopada 2014.

3 M. Mycke-Dominko, Zmiany na obszarze Lasu Katyńskiego w latach 1942-1944 na podstawie analizy zdjęć lotniczych, „Fotointerpretacja w Geografii", 22, 1992, s. 111-123.

4 I. Ewiak, P. Brodowska, Wykorzystanie zasobu geoinformacyjnego do opracowania archiwalnych fotogrametrycznych danych obrazowych, „Archiwum Fotogrametrii, Kartografii i Teledetekcji”, 23, 2012, s. $101-110$. 
Oprócz zastosowań interpretacji zdjęć lotniczych w kartografii i fotogrametrii fotografie tego rodzaju są też jednym z narzędzi badania krajobrazu archeologicznego. Pozwalają na szersze spojrzenie, a także dostrzeżenie i zrozumienie elementów, które mogą być nieuchwytne z powierzchni ziemi. Jest to możliwe głównie dzięki tzw. wyróżnikom wegetacyjnym oraz glebowym, które ujawniają obecność obiektów archeologicznych. Warto zwrócić uwage na bogate doświadczenia polskiej archeologii w dziedzinie prospekcji aerofotograficznej. Wykonywanie zdjęć lotniczych stanowisk archeologicznych sięga w Polsce okresu międzywojennego. W 1935 r. zrobiono pierwszą tego rodzaju fotografię Biskupina oraz wiele zdjęć grodzisk wielkopolskich. Po drugiej wojnie światowej prowadzono dalsze badania, które koncentrowały się na wykonywaniu z helikopterów i samolotów zdjęć dokumentacyjnych stanowisk archeologicznych widocznych w krajobrazie, takich jak kurhany i przede wszystkim grodziska.

Zasadniczy przełom w podejściu do archeologii lotniczej w Polsce nastąił w 1996 r., przede wszystkim dzięki współpracy międzynarodowej - m.in. z międzynarodową organizacją skupiającą archeologów lotniczych Aerial Archaeology Research Group5.

Kontynuacją badań jest pilotażowy projekt Instytutu Archeologii Uniwersytetu Kardynała Stefana Wyszyńskiego w Warszawie wykorzystujący najnowsze technologie $\mathrm{w}$ archeologii i zastosowanie lotniczego skaningu laserowego LIDAR (Light Detection and Ranging) - bezinwazyjnej metody badawczej, która umożliwia m.in. weryfikację dotychczas rozpoznanych stanowisk archeologicznych i obiektów związanych z działalnością człowieka w przeszłości oraz wykrycie dotąd nieznanych. Skaning laserowy ma unikalną cechę przenikania przez pokrywę roślinną. Możliwe jest więc zdobycie informacji o ukształtowaniu terenu nawet pod gęstą roślinnością, np. lasem. Dane pozyskane metodą lotniczego skaningu laserowego $\mathrm{w}$ postaci $\mathrm{Nu}$ -

5 Z. Kobyliński, Siedemdziesiąt lat archeologii lotniczej w Polsce, Światowit", 42, 1999, s. 112-122. merycznego Modelu Terenu wykorzystano do wstępnego rozpoznania oraz weryfikacji stanu zachowania i występowania stanowisk archeologicznych w rejonie między Wartą, Koninem a Kołem ${ }^{6}$.

\section{Metodyka interpretacji zdjęć lotniczych}

Fotointerpretacja jest częścią szerszej dziedziny, którą nazywamy teledetekcją. O ile teledetekcja obejmuje zdalną rejestrację obiektów w różnych zakresach spektralnych, a także późniejsze przetwarzanie obrazów, to fotointerpretacja jest procesem identyfikacji oraz interpretacji obiektów i zjawisk na zdjęciach fotogrametrycznych.

Fotointerpretacja wizualna danych teledetekcyjnych, od lat niepodlegająca zasadniczym zmianom, opiera się na analizie bezpośrednich, pośrednich i kompleksowych cech rozpoznawczych obiektów zarejestrowanych na zdjęciu. Ton, rozmiar, tekstura, struktura, cień, wysokość, lokalizacja w stosunku do otoczenia - to główne cechy umożliwiające interpretatorowi rozpoznawanie obiektów zarejestrowanych na zdjęciu i wyciągnięcie wniosków co do ich wzajemnych zależności. W związku z dużą ilością szczegółów rozpoznawalnych na fotografii lotniczej istnieje wyraźna różnica pomiędzy tym, co można na niej zobaczyć, a informacją, którą na podstawie tych źródeł można wykorzystać do celów praktycznych. Ilość i jakość danych, które można uzyskać w oparciu o interpretację danych teledetekcyjnych, jest wypadkową doświadczenia i zdolności interpretatora. Powinien on umieć ocenić sfotografowany obszar i przekształcić go w obraz miejsca (najczęściej mu nieznanego), jak również dostarczyć informacji o działalności, jaka się tam odbywa7.

Widziany na zdjęciach lotniczych model środowiska geograficznego najczęściej przedstawiony jest w postaci kartograficznej. Zinterpretowaną treść rysuje się na przeźroczystych

\footnotetext{
${ }^{6}$ S. Zdziebłowski, Innowacyina technologia w archeologii (http:// naukawpolsce.pap.pl/aktualnosci/news,374181,innowacyjna-technologia-w-archeologii.html, dostęp: 13 czerwca 2015).

${ }^{7}$ A. Ciołkosz, A. Kęsik, Podstawy geograficznej interpretacji zdjęć Iotniczych, Lublin 1969.
} 
nakładkach lub bezpośrednio na zdjęciu, a następnie przenosi na podkład mapowy. Obecnie coraz częściej interpretacja danych teledetekcyjnych prowadzona jest metodą wizualno-manualną ze wspomaganiem komputerowym.

\section{Detekcja elementów antropogenicznych okolic Jedwabnego}

W związku z prowadzonymi przez Instytut Pamięci Narodowej (Oddziałowa Komisja Ścigania Zbrodni przeciwko Narodowi Polskiemu żyńskim, będącego siedzibą gminy wiejsko-miejskiej. Prace studialne obejmowały tereny leżące na północ od Jedwabnego w sąsiedztwie cmentarzy katolickiego i żydowskiego (ryc. 1). Zadaniem ekspertyzy było:

1. określenie charakteru konstrukcji ziemnej o kształcie linii widniejącej na terenie cmentarza żydowskiego;

2. rozpoznanie, czy na analizowanym terenie znajdują się podobne konstrukcje ziemne i jak należy je interpretować;

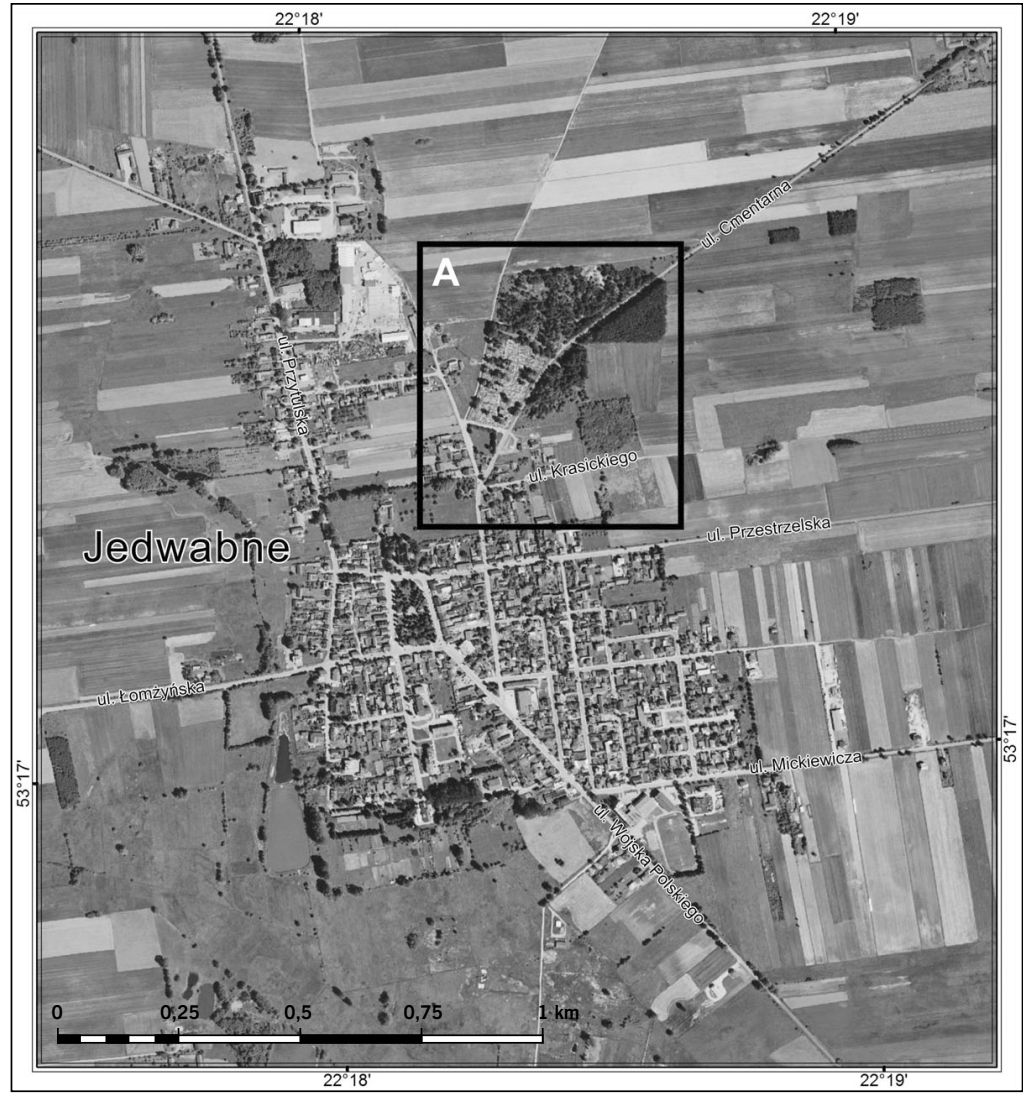

Ryc. 1. Jedwabne - obszar analizy (A). Źródto: http://geoportal.gov.pl, dostęp: 20 października 2014

w Białymstoku) badaniami dotyczącymi zabójstwa obywateli polskich narodowości żydowskiej w dniu 10 lipca 1941 r. w Jedwabnem Instytut Geodezji i Kartografii przeprowadzit w 2002 r. ekspertyzę w zakresie detekcji obiektów antropogenicznych okolic tego miasta - leżącego w województwie podlaskim, w powiecie łom-
3. objaśnienie, czy na terenie cmentarza żydowskiego i w jego okolicach występują zmiany pokrycia terenu, których rozmiary i wygląd przemawiają za przyjęciem, iż w miejscach tych mogą znajdować się mogity zbiorowe;

4. określenie, czy na obszarze leżącym na południe od granicy cmentarza żydowskiego 
w pasie po obu stronach równoległej do cmentarza drogi widoczne są ślady wskazujące, iż tereny te w czasie wykonywania zdjęcia lotniczego stanowiły użytki rolne.

\section{Materiał źródłowy}

Wyniki prac geodezyjnych i kartograficznych, które prowadzono w ciągu ostatnich kilkudziesięciu lat, stały się podstawą Państwowego Zasobu Geodezyjnego i Kartograficznego. Zasób ten składa się m.in. z map, materiałów fotogrametrycznych i teledetekcyjnych (zdjęcia lotnicze i satelitarne), rejestrów, wykazów, informatycznych baz danych oraz katalogów danych geodezyjnych.

Państwowy zasób geodezyjny i kartograficzny obejmuje: zasób centralny - gromadzony w Centralnym Ośrodku Dokumentacji Geodezyjnej i Kartograficznej w Warszawie (CODGiK), zasoby wojewódzkie - gromadzone w wojewódzkich ośrodkach dokumentacji geodezyjnej i kartograficznej (WODGiK) oraz zasoby powiatowe - gromadzone w powiatowych ośrodkach dokumentacji geodezyjnej i kartograficznej.

Archiwum teledetekcyjne Państwowego Zasobu Geodezyjnego i Kartograficznego obejmuje zdjęcia lotnicze i ich przetworzenia pozyskiwane cyklicznie od 1972 r. Starsze zobrazowania lotnicze, pozyskane w latach 1945-1972, gromadzone są przez Centralne Archiwum Wojskowe ${ }^{8}$.

Archiwalne zdjęcia lotnicze znajdują się także w lokalnych zasobach internetowych. Przykładem jest serwis mapowy „Warszawa historyczna", w którym dostępna jest m.in. usługa przeglądania i udostępniania lotniczych fotoplanów i ortofotomap z lat 1935, 1939 i $1945^{\circ}$.

Zdjęcia Polski z okresu drugiej wojny światowej można znaleźć na stronie internetowej The National Collection of Aerial Photography (NCAP), udostępnianej w ramach Królewskiej Komisji ds. Zabytków Starożytnych i Historycznych Szkocji (Royal Commission

8 I. Ewiak, P. Brodowska, Wykorzystanie zasobu.

9 http://www.mapa.um.warszawa.pl/, dostęp: 5 grudnia 2014. on the Ancient and Historical Monuments of Scotland - RCAHMS). Na stronie tej dostępne są archiwalne zdjęcia rozpoznania lotniczego Królewskich Sił Lotniczych (RAF) z drugiej wojny światowej przechowywane

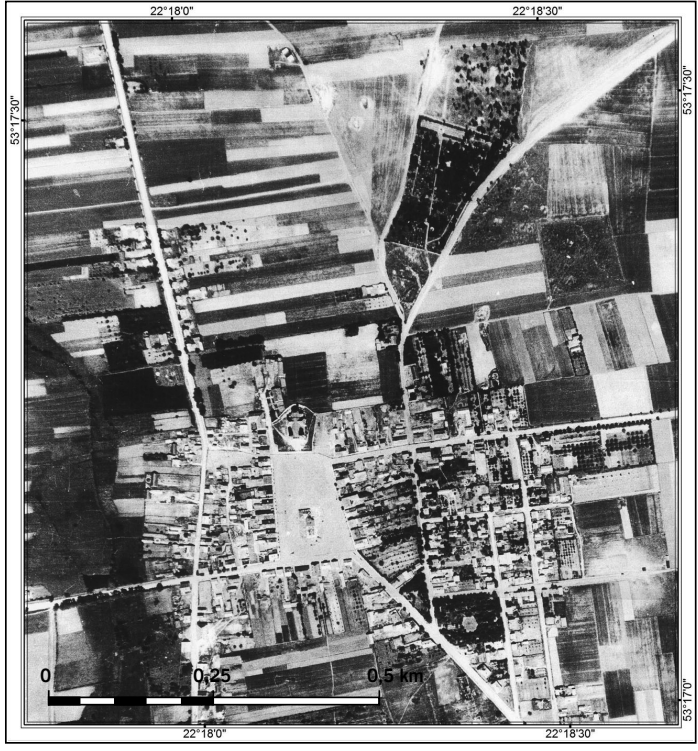

Ryc. 2A. Jedwabne - panchromatyczne zdjęcie lotnicze z 1951 r.

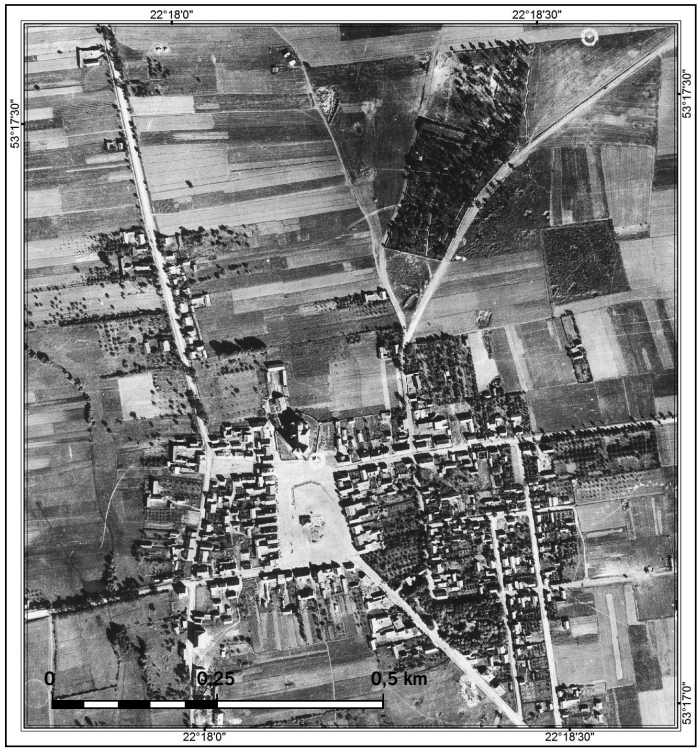

Ryc. 2B. Jedwabne - panchromatyczne zdjęcie lotnicze z 1953 r. Źródto: IPN - Oddziałowa Komisja Ścigania Zbrodni przeciwko Narodowi Polskiemu w Biatymstoku

\section{I44 Studia Geohistorica • Nr 03. 2015}


w Narodowym Archiwum Fotografii Lotniczej w Edynburgu ${ }^{10}$. Naczelna Dyrekcja Archiwów Państwowych udostępnia na swoich stronach m.in. ukośne zdjęcia lotnicze, które zostały wykonane na początku lat 30. XX w. przez firmę Junkers-Luftbild ${ }^{11}$.

W ostatnich latach wykorzystanie danych teledetekcyjnych w studiach historyczno-geograficznych systematycznie wzrasta, co wynika głównie z obniżenia cen zdjęć archiwalnych oraz ułatwienia dostępu do nich poprzez rozwój Internetu. Coraz częściej można już nie tylko zamówić zgromadzone dane, ale również przeglądać lub nawet bezpośrednio pobrać je na własny komputer.

Podstawą analizy obiektów antropogenicznych były panchromatyczne zdjęcia lotnicze okolic Jedwabnego. Pierwsze z nich to zdjęcie o wymiarach $49,6 \times 59,5 \mathrm{~cm}$ w przybliżonej skali 1:3000 wykonane w 1951 r. (ryc. 2A), drugie - o wielkości $49,6 \times 58,6 \mathrm{~cm}$ w przybliżonej skali 1:2500 wykonane w $1953 \mathrm{r}$. (ryc. 2B). Zdjęcia lotnicze nie miały pokrycia stereoskopowego i charakteryzowały się nienajlepszą jakością.

\section{Przebieg badania}

Pierwszym etapem postępowania fotointerpretacyjnego była poprawa czytelności obiektów i zjawisk zarejestrowanych na zdjęciach lotniczych. Szczególną uwagę zwrócono na podkreślenie krawędzi obiektów występujących w obrębie badanego zdjęcia lotniczego oraz podkreślenie jednorodnej grupy użytków i granic sąsiadujących ze sobą obszarów o odmiennym sposobie wykorzystania. W tym celu dobrano odpowiednią jasność oraz wzmocniono kontrast zdjęć.

Następnym etapem była analiza przetworzonych fotografii. Proces interpretacji panchromatycznych zdjęć lotniczych polegał na wykryciu i rozpoznaniu antropogenicznych form pokrycia ziemi na podstawie bezpośrednich, pośrednich i kompleksowych cech rozpoznawczych zarejestrowanych obiektów.

$10 \mathrm{http}: / /$ ncap.org.uk/, dostęp: 5 grudnia 2014

11 http://www.archiwa.gov.pl, dostęp: 5 stycznia 2015
Obiekty antropogeniczne są tymi elementami terenu, które powstały w wyniku działalności człowieka. Zaliczamy do nich m.in. rolnicze użytkowanie ziemi, sieć komunikacyjną, infrastrukturę techniczną czy urządzenia przemysłowe. W wielu przypadkach obiekty antropogeniczne pozostają w ścisłym związku z elementami krajobrazu naturalnego, które warunkują ich położenie, rozmiar i kształt ${ }^{12}$.

W detekcji obiektów antropogenicznych okolic Jedwabnego szczególną uwagę zwrócono na:

- wielkość i kształt obiektów. Parametry te należą do bezpośrednich cech rozpoznawczych obiektów i są elementarnymi właściwościami obrazów obiektów, które łatwo dostrzec na zdjęciach lotniczych. Obrys wydzieleń wskazuje najczęściej na charakter obiektu i pozawala na określenie, czy powstał on w wyniku działalności człowieka (o czym świadczy najczęściej regularny kształt, zbliżony do figur geometrycznych), czy też ma charakter naturalny (nieregularny kształt);

- strukturę i teksturę obrazu. Cechy te są ze sobą ściśle powiązane i odzwierciedlają charakter powierzchni sfotografowanego obiektu. Sposób uporządkowania drobnych punktów czy plamek, które tworzą powierzchnię obrazu, pozwala na odróżnienie i klasyfikację obiektów o odmiennej budowie (np. regularna struktura obrazu cmentarza pozwala odróżnić go od lasu o ziarnistej, nieregularnej strukturze, od ziarnistej struktury pól uprawnych czy bezstrukturalnego obrazu łąk);

- zróżnicowanie tonalne obrazu, które jest podstawową cechą rozpoznawczą obiektów zarejestrowanych na zdjęciu. Ton panchromatycznego zdjęcia lotniczego pozostaje w ścisłej zależności od charakterystyki spektralnej zobrazowanego obiektu. Tereny pozbawione roślinności lub te, na których prowadzone są prace ziemne, odwzorowują się na odbitce pozytywowej w jasnym fotofonie;

- rozmieszczenie i wzajemną lokalizację obiektów, które są pośrednimi cechami rozpoznawczymi wskazującymi poprzez jedne

\footnotetext{
12 A. Ciołkosz, A. Kęsik, Podstawy geograficznej interpretacji.
} 


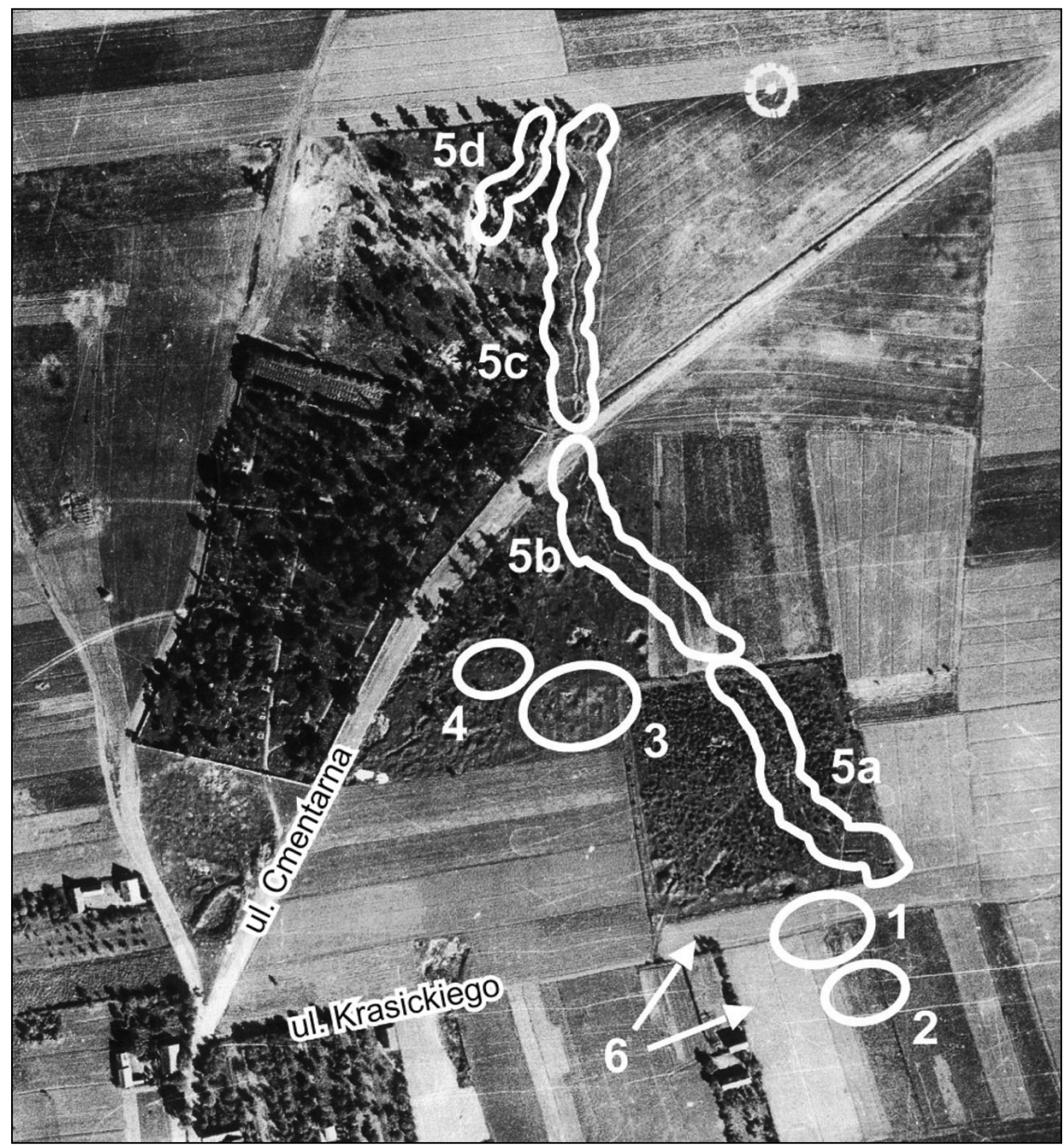

Ryc. 3. Jedwabne - szkic fotointerpretacycjny (panchromatyczne zdjęcie lotnicze z 1953 r.).

Źródło: IPN - Oddziałowa Komisja Ścigania Zbrodni przeciwko Narodowi Polskiemu w Białymstoku

obiekty i ich właściwości na obecność lub odrębność innych.

Interpretacja monoskopowa panchromatycznych zdjęć lotniczych pozwoliła na wyznaczenie i charakterystykę obiektów będących przedmiotem ekspertyzy. Ich lokalizację przedstawiono na ryc. 3 .

Cmentarz żydowski w Jedwabnem położony jest ok. $200 \mathrm{~m}$ od zabudowań. Przed wojną teren nekropolii był ogrodzony niskim parkanem. Obecnie od strony drogi cmentarz otoczony jest murem z bloków skalnych, a jego teren porasta gęsty las. W środkowej części nekropolii na panchromatycznych zdjęciach lotniczych z 1951 i 1953 r. można zaobser- wować ciągnącą się na długości ok. $140 \mathrm{~m}$ konstrukcję ziemną w postaci łamanych i krętych rowów, które można interpretować jako pozostałość okopów z okresu drugiej wojny światowej (ryc. 3, sygn. 5a).

Linia dawnych okopów znajduje swoje przedłużenie na północ od cmentarza żydowskiego. Zaobserwowana konstrukcja ziemna przebiega przez grunty orne, gdzie jej rysunek jest mocno zatarty w wyniku prowadzonej orki, następnie biegnie przez teren zakrzaczonego nieużytku w bezpośrednim sąsiedztwie cmentarza katolickiego i dalej wzdłuż granicy kompleksu zadrzewień. Dochodząc na północy do obszaru gruntów ornych, linia dawnych 
okopów urywa się (ryc. 3, sygn. 5b). W obrębie rzadkich zakrzaczeń na północ od cmentarza żydowskiego znajdują się kolejne dwa niewielkiej długości odcinki dawnych okopów (ryc. 3, sygn. 5c i 5d).

W wyniku przeprowadzonych analiz zostały również wyznaczone obiekty antropogeniczne o charakterze powierzchniowym (ryc. 3, późniejsze prace archeologiczne w Jedwabnem, które ujawniły, że stodoła, w której doszło do tragedii, miała $19 \mathrm{~m}$ długości i $7 \mathrm{~m}$ szerokości (ryc. 4). Mogiła, w której pochowano spalone osoby, ma wymiary $7,5 \times 2,5 \mathrm{~m}$ i znajduje się przy dłuższym $\mathrm{z}$ boków stodoły. $\mathrm{Na}$ prośbę środowisk żydowskich jej głębokość nie była dokładnie badana. Ustalono jedynie,

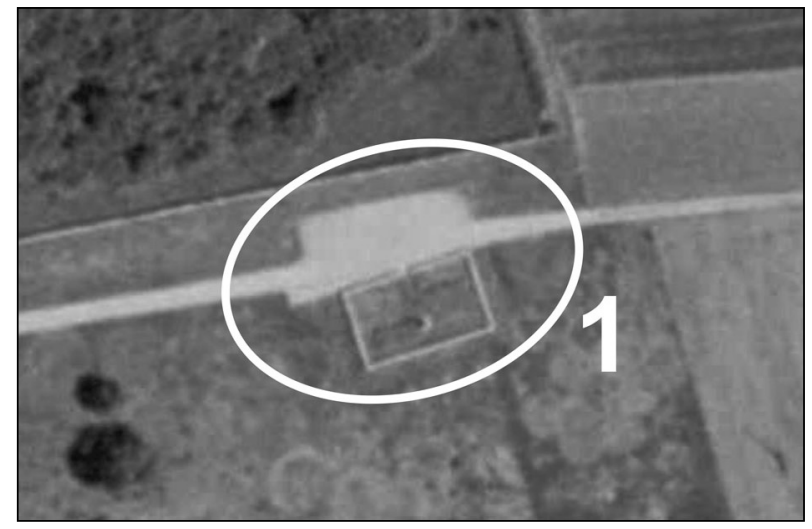

Ryc. 4. Lokalizacja stodoły, w której 10 lipca 1941 r. spalono żywcem większość żydowskich mieszkańców Jedwabnego. Żródło: http://geoportal.gov.pl/, dostęp: 20 października 2014

sygn. 1-4). Obiekty te charakteryzują się regularnym, geometrycznym zarysem oraz odrębną strukturą i fototonem. Jasny fototon i regularne granice, a także zaburzenia naturalnego układu warstwy glebowej i podglebia podkreślają ich antropogeniczny charakter. Zasięg powierzchniowy wydzielonych obiektów - zarówno na zdjęciach lotniczych z 1951, jak i z 1953 r. - różni się nieznacznie okonturowaniem, co jest wynikiem zróżnicowań tonalnych obydwu zdjęć, jednak położenie owych obiektów jest identyczne.

Obiekty antropogeniczne oznaczone na ryc. 3, sygn. 1 i 2 są usytuowane na południe od cmentarza żydowskiego, przy polnej drodze prowadzacej do Jedwabnego. W odniesieniu do obiektu oznaczonego sygn. 1 (ryc. 3) można z dużym prawdopodobieństwem stwierdzić, że w tym miejscu znajdowała się stodoła, w której spalono żywcem większość z żydowskich mieszkańców miasta, oraz zbiorowa mogiła ofiar zbrodni. Przypuszczenia te potwierdziły że grubość przykrywającej ją warstwy ziemi (tzw. nadkładki) wynosi $50-130 \mathrm{~cm}^{13}$.

Charakter wydzielenia oznaczonego sygn. 2 (ryc. 3) wskazuje na prowadzenie na tym obszarze prac ziemnych, o czym świadczy m.in. zaburzenie naturalnego układu warstwy glebowej.

Dwa pozostałe powierzchniowe obiekty antropogeniczne oznaczone sygn. 3 i 4 (ryc. 3) zlokalizowane są w sąsiedztwie cmentarza żydowskiego, po jego zachodniej stronie. Charakter tych obiektów oraz zaburzenie naturalnego układu warstwy glebowej i podglebia mogą wskazywać na prowadzenie na tym obszarze prac ziemnych. Ich lokalizacja i odległość od miejsca zbrodni nie pozawalają jednak na jednoznaczne wnioskowanie, że są to obszary występowania mogił zbiorowych.

Na podstawie dostępnych materiałów fotolotniczych (zaburzenia tonalno-strukturalne

13 Mord w Jedwabnem (http://www.polskieradio.pl/39/156/Artykul/633456,Mord-w-Jedwabnem, dostęp: 8 października 2014). 
oraz niewielkie zagłębienia) nie można sformułować jednoznacznego wniosku, że obszar żydowskiej nekropolii jest miejscem pochówku ofiar z 1941 r.

$\mathrm{Na}$ podstawie cech rozpoznawczych, które są właściwe dla rolniczych form użytkowania ziemi, możliwe jest jednoznaczne ustalenie, że tereny położone na południe od granicy cmentarza żydowskiego oraz leżące w pasie po obu stronach drogi polnej biegnącej równolegle do cmentarza żydowskiego w czasie wykonywania zdjęć (w 1951 i 1953 r.) były użytkowane rolniczo (ryc. 3, sygn. 6).

\section{Podsumowanie}

Bardzo często efektywność archiwalnych zdjęć lotniczych oceniana jest z perspektywy współczesnych parametrów technicznych i zaawansowanych metod przetwarzania danych teledetekcyjnych, przez co ich użyteczność bywa wielokrotnie niedoceniana. Wieloletnie doświadczenia Instytutu Geodezji i Kartografii wskazują na znaczącą rolę archiwalnych zdjęć lotniczych w analizach retrospektywnych. Ich wykorzystanie umożliwia $\mathrm{z}$ reguły znacznie dokładniejsze opisanie terenu w stosunku do mapy topograficznej. Zdjęcia lotnicze pozwalają na zarejestrowanie w ściśle określonym czasie pełnego obrazu wszystkich elementów występu-

\section{Bibliografia}

\section{Literatura}

Ciołkosz A., Kęsik A., Podstawy geograficznej interpretacji zdjęć lotniczych, Lublin 1969.

Ciołkosz A., Mieszalski J., Olędzki J.R., Interpretacja zdjęć lotniczych, Państwowe Wydawnictwo Naukowe, Warszawa 1999, s. 11-17.

Ewiak I., Brodowska P., Wykorzystanie zasobu geoinformacyjnego do opracowania archiwalnych fotogrametrycznych danych obrazowych, „Archiwum Fotogrametrii, Kartografii i Teledetekcji”, 23, 2012, s. 101-110.

Kobyliński Z., Siedemdziesiąt lat archeologii lotniczej w Polsce, „Światowit”, 42, 1999 , s. 112-122. jących na powierzchni ziemi. Stwarza to możliwość detekcji obiektów i obszarów historycznych ze szczegółowością większą od tej, którą dostrzega się, porównując mapy i dokumenty z różnych okresów, co powoduje, że archiwalne zdjęcia lotnicze mogą być cennym źródłem w studiach historyczno-geograficznych.

Obecnie na zlecenie Oddziałowej Komisji Ścigania Zbrodni przeciwko Narodowi Polskiemu w Białymstoku IPN Instytut Geodezji i Kartografii przygotowuje opinię w sprawie śledztwa dotyczącego tzw. obławy augustowskiej. Zespół IGiK w składzie dr Dariusz Dukaczewski, mgr inż. Karol A. Karwel i mgr inż. Honorata Paradyż podjął prace mające na celu ustalenie miejsc o zakłóconej strukturze powierzchni ziemi, wskazujących na możliwość istnienia jam grobowych na terenie przyległym do budynku przy ul. 3 Maja 16 w Augustowie, wzdłuż tras transportu zatrzymanych (Giby - Rygol - Giedź - Kalety; Giby - Stanowisko - Kalety) oraz w rejonie miejscowości Giedź i Kalety (na terenie Republiki Białorusi). Prace te były wykonywane $\mathrm{z}$ wykorzystaniem dawnych i współczesnych zdjęć lotniczych oraz chmury punktów skaningu laserowego (w części polskiej), jak również wysokorozdzielczych danych satelitarnych (dla części polskiej i białoruskiej).

Mord w Jedwabnem (http://www.polskieradio. pl/39/156/Artykul/633456, Mord-w-Jed wabnem, dostęp: 8 października 2014).

Mycke-Dominko M., Zmiany na obszarze Lasu Katyńskiego w latach 1942-1944 na podstawie analizy zdjęćlotniczych, „Fotointerpretacja w Geografii”, 22, 1992, s. 111-123.

Zdziebłowski S., Innowacyjna technologia $w$ archeologii (http://naukawpolsce.pap.pl/aktual nosci/news,374181, innowacyjna-technologia-w -archeologii.html, dostęp: 13 czerwca 2015). 
Źródła internetowe

http://geoportal.gov.pl/, dostęp: 20 października 2014.

http://www.mapa.um.warszawa.pl/, dostęp: 5 grudnia 2014.

http://ncap.org.uk/, dostęp: 5 grudnia 2014. https://www.herder-institut.de/atlas-miast -slaskich, dostęp: 13 listopada 2014.

\section{Identification of Anthropogenic Objects on Archival Aerial Photographs of Jedwabne Area}

\section{Summary}

In connection with the research conducted by the Institute of National Remembrance relating to the participation in the murder of Polish citizens of Jewish nationality on 10 July 1941 in Jedwabne, in 2002 the Institute of Geodesy and Cartography provided an expertise in the field of the anthropogenic object detection in the Jedwabne area. The article presents the methodology and results of the analysis of archival aerial photographs concerning the assessment of anthropogenic forms.

The results confirm a significant role played by archival aerial photographs in retrospec-

tive analyses. The use of aerial photographs usually enables a more accurate description of the site compared to a topographic map. Aerial photographs make it possible to register a complete picture of all the elements present on the surface of the earth at a specific time. This creates a possibility to detect constructions and historical areas with details greater than by comparing maps and documents from various periods, which makes archival aerial photographs a valuable source of historical-geographical studies.

Słowa kluczowe: zdjęcia lotnicze, fotointerpretacja, obiekty antropogeniczne

Keywords: aerial photos, photointerpretation, anthropogenic objects

mgr Anna Mirończuk - asystent w Instytucie Geodezji i Kartografii w Warszawie, wykonawca projektów badawczych, w których zajmuje się wizualizacją, analizą oraz przetwarzaniem danych przestrzennych w systemach GIS

(e-mail: anna.mironczuk@igik.edu.pl)

dr Zenon F. Poławski - zatrudniony w Zakładzie Kartografii Instytutu Geodezji i Kartografii w Warszawie, wykonawca wielu ekspertyz i projektów badawczych związanych z zastosowaniem metod teledetekcyjnych do kartowania tematycznego oraz z opracowaniem metod wizualizacji wyników tych badań (e-mail: zenon.polawski@igik.edu.pl) 